\title{
PELATIHAN PERAWATAN DAN PERBAIKAN PERALATAN LISTRIK RUMAH TANGGA BAGI MASYARAKAT RUKUN WARGA 09 KELURAHAN BUNULREJO - KOTA MALANG
}

\author{
Heri.S ${ }^{1}$, M.Mieftah ${ }^{2}$ Sukamdi ${ }^{3}$ Slamet.N ${ }^{4}$,Epiwardi ${ }^{5}$ \\ Jurusan Teknik Elektro, Program Studi Teknik Listrik, Politeknik Negeri Malang \\ e-mail: heridalimin@gmail.com ${ }^{1}$,
}

\begin{abstract}
Abstrak - Maintenance and repair of household electrical appliances for the Rukun community Residents 09 Bunulrejo Village / Kec. Blimbing Malang City, gives additional the skills and motivation for the Rukun Community of 09 Bunulrejo Village for practice maintenance and repair of household electrical appliances for the Rukun community Residents 09 Bunulrejo Village. Besides that it can also improve skills addition to the community of Rukun Warga 09 Kelurahan Bunulrejo in the field of care and repair of household electrical appliances for the 09 Rukun Warga community in the Village Bunulrejo that applies in this era.
\end{abstract}

Kata kunci: Maintenance, repair ,household electrical

\section{PENDAHULUAN}

\subsection{Latar Belakang}

Kondisi lingkungan di pelatihan perawatan dan perbaikan peralatan listrik rumah tangga bagi masyarakat Rukun Warga 09 Kelurahan Bunulrejo/Kec. Blimbing - Kota Malang. Untuk sasat ini yang keinginan untuk mengembangkan modul modul praktek khususnya yang berkaitan dengan peralatan listrik rumah tangga kurang dapat dipahami oleh masyarakat Rukun Warga 09 dalam bidang praktek,sehingga menghambat kemajuan praktek perawatan dan perbaikan peralatan listrik rumah tangga

Di rukun warga 09. terdapat 30 pemuda-pemudi masyarakat Rukun Warga 09 Kelurahan Bunulrejo/Kec. Blimbing - Kota Malang

Berdasarkan kedua kondisi di atas, yaitu kondisi lingkungan dan kondisi potensi sumber daya manusia para pengajari, maka dapat diambil suatu peluang untuk dapat melaksanakan pengabdian pada masyarakat. Pengabdian pada masyarakat tersebut berbentuk pelatihan perawatan dan perbaikan peralatan listrik rumah tangga bagi masyarakat Rukun Warga 09 Kelurahan Bunulrejo/Kec. Blimbing - Kota Malang, sehingga nantinya dapat menambah keterampilan para pengajar dalam bidang instalasi listrik dan praktek kendali. Kemudian diharapkan mereka dapat berupaya untuk melaksanakan pelatihan perawatan dan perbaikan peralatan listrik rumah tangga bagi masyarakat Rukun Warga 09 Kelurahan Bunulrejo/Kec. Blimbing - Kota Malang, sehingga dapat pelaksanaan praktek yang berlaku.

\subsection{Tujuan Kegiatan}

1. Memberikan tambahan pengetahuan dan keterampilan pelatihan perawatan dan perbaikan peralatan listrik rumah tangga bagi masyarakat Rukun Warga 09 Kelurahan Bunulrejo/Kec. Blimbing - Kota Malang

2. Memotivasi para pemuda -pemudi untuk pengembangan sasarana praktek guna memenuhi target yang berlaku

\section{TINJAUAN PUSTAKA}

Pelatihan Perawatan dan Perbaikan Peralatan Listrik Rumah Tangga khususnya instalasi Peralatan Listrik Rumah Tangga mencakup pengetahuan tentang teknik pengendalian peralatan listrik, standar/peraturan, dan teknik pemasangan. Dimana ketiga komponen tersebut harus memenuhi kebutuhan pengguna, terjaminnya keselamatan bagi manusia dan lingkungannya (Harten, Edi Setiawan. 1981: 27 ). Adapun rencana materi yang akan diberikan meliputi: Pengantar dasar instalasi listrik, Cara perbaikan dan perawatan Peralatan Listrik Rumah Tangga,Instalasi Listrik, Peralatan Instalasi, Standar/peraturan.

Ada tiga hal yang sangat penting yang harus diikuti untuk memperbaiki suatu peralatan:

1. Selalulah--dengan tanpa kecuali--yakinkan bahwa sumber listrik dan/atau sumber gas ke peralatan telah terputus sebelum Anda memulai mengetes peralatan untuk mendiagnose permasalahan, atau mereparasinya. Jika Anda memasukkan sumber listrik untuk mengecek pekerjaan Anda setelah perbaikan, jangan menyentuh peralatan; tetapi lihatlah (telitilah) dulu. Jangan pernah menyentuh peralatan hingga peralatan berjalan. Jika pengaturan diperlukan, matikan sumber sebelum Anda melakukannya.

2. Jika ada bagian peralatan yang dipegang (dikencangkan) dengan sekrup, baut, penyumbat, dan juga pengunci, Anda dapat segera menyiapkan berbagai keperluan untuk perbaikan. jika bagian peralatan dipegang dengan paku keling atau dilas, jangan coba-coba untuk memperbaiki peralatan sendiri; panggillah tenaga servis profesional. (Harten, Edi Setiawan. 1981: 30)

3. Dalam banyak hal, kerusakan atau ketidakfungsian bagian dari peralatan dapat diganti dengan lebih cepat dan tidak begitu mahal jika dibandingkan dengan memperbaikinya, oleh Anda atau oleh tenaga profesional. Mengganti kerusakan atau bagian yang tidak berfungsi dengan komponen baru yang sejenis. Suku cadang alat tersebut dapat diperoleh di pusat-pusat servis alat, dealer, dan toko-toko suku cadang. Anda tidak selalu harus pergi ke pusat servis di daerah Anda, 
pesanlah komponen yang Anda butuhkan langsung ke pabrik; berilah pabrik data tentang model dan komponen yang mungkin untuk alat tersebut. Nama dan alamat pabrik biasanya tercatat di alat tersebut.( PUIL $2000: 25$ )

\subsection{Peralatan Blender}

Blender, seperti halnya mixer, adalah peralatan dapur yang sangat pokok, untuk pemotong, pencampur, pengental, dan pencair makanan. Blender terdiri dari sebuah botol (stopfles) kaca atau plastik pada bagian dasarnyasebagai rumah motor universal, dan bilah pemotong dirakit di dalam stopfles, digerakkan oleh motor pada bagian bawah. Kebanyakan blender memiliki problem pada bilah dan poros yang merupakan rakitan untuk pemotong.

\subsection{Pembongkaran}

Untuk mengerjakan blender, Anda harus membongkar rakitan pemotong dan membuka dasarnya untuk mengambil motornya. Stopfles mungkin di dalam salah satu bagian, terdapat bilah pemotong yang disegel padabagian bawah unit. Untuk mengeluarkan segel, angkat stopfles dari dasar dan lepaskan mur kopling di bawah stopfles. Gunakan kain untuk melindungi jari-jari Anda, pegang sisi-sisi bilah di dalam stopfles dan putar pengkopel searah jarum jam (cw) untuk melepaskannya; kemudian angkat bilah. Jika bagian-bagiannya belum dapat bergerak, putar pengkopel berlawanan arah jarum jam (ccw) untuk melepaskannya; beberapapengkopel dapat dilepas dengan cara ini. Hingga Anda yakin pengkopel menggunakan cara memutar yang mana untuk mengeluarkannya, jangan gunakan kekerasan sedikitpun; Anda akan memecahkannya.

Pada beberapa unit, pengkopel berputar ccw untuk membukanya. Jika kopling terdiri dari kancing logam yang dipasang pada bagian bawah stopfles, masukkan paku melalui lobang ventilasi pada bagian rumah/bodi landasan, dan lawanlah bilah-bilah pada kipas dengan paku untuk menjaga poros dari putaran. Kemudian lepas kancing dengan kunci Inggris dengan memutar $\mathrm{cw}$ atau $\mathrm{ccw}$.

\section{3 .Pembersihan}

Kipas angin dan bilah pemotong yang dirakit pada blender harus dibersihkan secara periodik untuk menjaga efisiensi kerja blender. Untuk membersihkan bilah-bilah, lepaskan kopling dari stopfles, dan keluarkan bilah-bilah,poros, gelang-tutup (ring), rumah bantalan, dan mur yang menyusun rakitan pemotong. Susunlah bagian-bagian ini seperti ketika Anda membongkar blender, dan buatlah diagram seperti yang Anda kerjakan sehingga Anda dapat merakit kembali pemotong ini dengan benar. Bersihkan bagian-bagian ini di dalam larutan air dan sedikit detergen, dan keringkan sepenuhnya. Ujilah bilah pemotong dan bantalannya dengan hati-hati, bagian inilah yang pokok dan sering rusak. Jika bagian ini terlihat rusak, gantilah dengan yang baru.

\subsection{Operasi Gangguan}

Jika blender banyak terganggu, permasalahan kebanyakan pada kopling atau kipas. Kopling atas adalah bagian bawah dari rakitan poros pemotong; kopling bawah adalah bagian atas 'base' dimana stopflesdipasangkan ke motor. Jika kopling yang lain kelihatan aus, gantilah dengan yang baru yang sejenis; pasangkan kopling yang baru seperti pada pasangan kopling yang lama.

Gangguan yang luar biasa atau sangat menyolok biasanya disebabkan oleh sudu kipas yang bengkok atau hancur. Untuk menyelesaikan permasalahan ini, bukalah 'base' pada unit dan bersihkan dan periksalah sudu-sudu kipas. Jika sudu-sudu agak bengkok, luruskanlah dengan tang; jika Anda tidak dapat meluruskannya, gantilah rakitan sudu-sudu kipas. Untuk mengeluarkan rakitan sudu-sudu kipas, lepaskan mur penguat yang memegangnya pada poros motor; atau, jika rakitan sudu adalah sangat bergeser, tariklah keluar. Gantilah rakitan sudu-sudu dengan yang baru yang sejenis; pasangkan rakitan baru dengan cara yang sama seperti pada rakitan yang

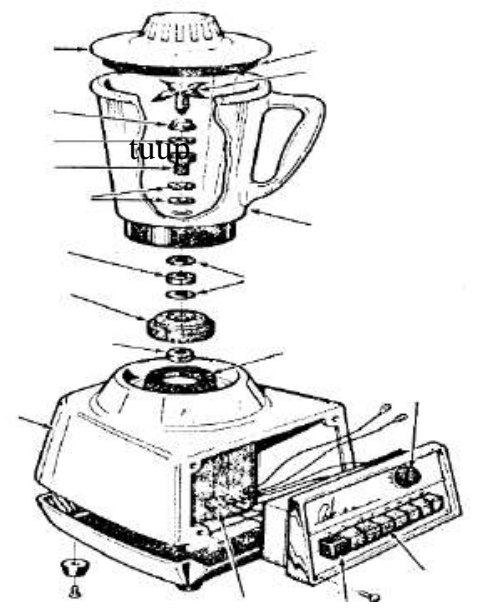

Gambar 2.1 Sebuah blender mempunyai rakitan bilah pemotong yang digerakkan oleh motor universal.

\subsection{Mesin Cuci}

Mesin cuci sangat komplek, untuk mendiagnose peralatan ini memerlukan waktu yang lebih lama dari pada menggantinya - penyebab yang terbesar pada putaran waktu khusus yang mengoperasikan katupdan motor yang menghidupkan air, putaran bak cuci (drum), aliran air, dan pengontrolan suhu air. Tetapi diagnosis dapat dilakukan; semua dapat dilakukan dengan alur logika dan kesabaran.

\subsection{Cara Pengoperasian Dasar}

Yakinkan bahwa mesin cuci sedang menerima daya listrik. Cek kabel, steker, dan KK, jika terdapat sakelar pengontrol KK di dinding, yakinkan bahwa sakelar sedang bekerja. Lihat pengaman lebur atau CB pada panel masuk utama; perbaiki rangkaian. Jika unit menerima daya dan sampai tidak berputar, tekan tombol kembali pada panel kontrol, jika mesin cuci memilikinya. 
Kedua, yakinkan bahwa tombol kontrol diset dengan baik dan pintu tertutup rapat. Ceklah untuk meyakinkan bahwa ia bebas dari serat-serat dan penambahan sabun.

Ketiga, yakinkan bahwa kedua keran air terbuka, dan bahwa saluran dan pipa kembali penyimpan sabun diperpanjang (ditempatkan) dengan baik, tanpa kesempitan (hambatan). Jika mesin cuci mempunyai tombol penyimpan air, yakinkan bahwa tombol ditekan; air tidak boleh mengalir melalui penyaring pipa semprot jika keranjang tidak penuh dan tombol tidak ditekan.

Akhirnya, yakinkan bahwa suhu air pantas. Cek sakelar selektor suhu pada panel kontrol untuk meyakinkan bahwa ia telah diset dengan baik. Juga kontrol suhu pemanas air; itu harus diset lebih rendah dari $120^{\circ} \mathrm{F}$.

\subsection{Refrigerator dan Freezer}

Refrigerator dan freezer, seperti halnya AC, terdiri dari dua komponen pokok -- sebuah coil condenser dan sebuah coil evaporator. Bahan pendingin cair disirkulasikan melalui coil-coil ini oleh sebuah kompressordan sebuah motor. Cairan bahan pendingin didinginkan di dalam condenser; lalu dialirkan ke evaporator. Pada evaporator, udara di dalam unit didinginkan oleh kontaknya udara dengan coil yang berisi cairan. Condenser pada refrigerator atau freezer adalah coil yang terletak diluar unit; evaporator adalah coil yang terletak di dalam unit. Bahan pendingin disirkulasikan melalui sistem ini oleh sebuah kompressor.

Sistem unit kompressor, yang menggerakkan bahan pendingin melalui sistem coil, digerakkan oleh sebuah motor kapasitor. Komponen-komponen dasar yang lain pada sistem pendingin/defrost (penghancur bunga es) termasuk sakelar, termostat, heater (pemanas), condenser, dan kipas. Anda dapat menguji dan mengganti beberapa komponen refrigerator ini. Bagaimanapun, ada pengecualian, seperti tercatat dalam prosedur berikut, yang terbaik serahkan ke servis profesional.

\section{MATERI DAN METODE}

\subsection{Khalayak Sasaran}

Pelatihan perawatan dan perbaikan peralatan listrik rumah tangga bagi masyarakat Rukun Warga 09 Kelurahan Bunulrejo/Kec. Blimbing - Kota Malang.

\subsection{Metode PKM}

Untuk menentukan metode PKM maka sistem pengajaran praktek di program pengabdian masyarakat ini, harus diketahui modul penunjang apa yang sesuai dengan kurikulum yang berlaku dan SDM pengajar yang ada dulu, guna memenuhi sasaran yang tepat .Oleh karena itu dengan pengetahuan dan keterampilan cara merancang, pelatihan perawatan dan perbaikan peralatan listrik rumah tangga bagi masyarakat Rukun Warga 09 Kelurahan Bunulrejo/Kec. Blimbing - Kota Malang dan peraturan instalasi listrik yang sesui PUIL 2000.

Dengan dibuatkan buku panduan teori dan praktek pelatihan perawatan dan perbaikan peralatan listrik rumah tangga bagi masyarakat Rukun Warga 09 Kelurahan Bunulrejo/Kec. Blimbing - Kota Malang sangat cocok untuk penunjang pelatihan perawatan dan perbaikan peralatan listrik rumah tangga bagi masyarakat Rukun Warga 09 Kelurahan Bunulrejo/Kec. Blimbing - Kota Malang sekarang bukan lagi barang yang baru, melainkan sesuatu yang harus terpenuhi demi kemajuan dan pemenuhan kebutuhan masyarakat mengenai pemanfaatan ketenagalistrikan tersebut.

Kegiatan pelatihan perawatan dan perbaikan peralatan listrik rumah tangga bagi masyarakat Rukun Warga 09 Kelurahan Bunulrejo/Kec. Blimbing - Kota Malang ini, dilaksanakan dengan metode langsung praktek, yaitu:

1. Pengenalan peralatan dan teori standar instalasi listrik sesuai PUIL 2000

2. Pengenalan pelatihan perawatan dan perbaikan peralatan listrik rumah tangga bagi masyarakat Rukun Warga 09

3. Pelatihan perawatan dan perbaikan peralatan listrik rumah tangga ini dipilih karena mengingat keterbatasan waktu, tenaga, dan dana yang tersedia.

\subsection{Rancangan Evaluasi}

Evaluasi diadakan pada hari kedua, yaitu di akhir acara, meliputi:

1. Demontrasi, presentasi dan wawancara langsung terhadap peserta pelatihan.

2. Pelatihan perawatan dan perbaikan peralatan listrik rumah tangga bagi masyarakat Rukun Warga 09 Kelurahan Bunulrejo/Kec. Blimbing Kota Malang Disamping itu untuk melihat secara nyata, hasil ketrampilan yang telah diajarkan kepada masyarakat. secara keseluruhan, akan dilakukan peninjauan langsung oleh tim pelaksana 15 hari kemudian

\section{PEMBAHASAN}

Berdasarkan metode yang diterapkan dalam pelaksanaan pengabdian kepada masyarakat ini, maka dapat dicapai hasil antara lain :

Metode materi, dan peragaan yang dilaksanakan dapat efektif mencapai tujuan yang diinginkan, jika dikaitkan dengan keterbatasan waktu pelaksanaan

Peserta pelatihan perawatan dan perbaikan peralatan listrik rumah tangga bagi masyarakat Rukun Warga 09 Kelurahan Bunulrejo/Kec. Blimbing - Kota Malang untuk perserta pelatihan dapat melihat langsung peralatan yang dipasang.

Peserta pelatihan dapat terampil melakukan pelatihan perawatan dan perbaikan peralatan listrik rumah tangga bagi masyarakat Rukun Warga 09 Kelurahan Bunulrejo/Kec. Blimbing - Kota Malang secara sederhana dengan baik dan standart. 
- Peserta pelatihan dapat mengatasi sendiri , jika ada permasalahan atau kerusakan pelatihan perawatan dan perbaikan peralatan listrik rumah tangga bagi masyarakat Rukun Warga 09 Kelurahan Bunulrejo/Kec. Blimbing - Kota Malang

- Peserta dapat menikmati secara langsung hasil dari praktek pelatihan perawatan dan perbaikan peralatan listrik rumah tangga bagi masyarakat Rukun Warga 09 Kelurahan Bunulrejo/Kec. Blimbing - Kota Malang

\section{KESIMPULAN DAN IMPLIKASI}

\subsection{Kesimpulan}

Setelah menelaah segala sesuatu yang berhubungan dengan aktivitas pelatihan perawatan dan perbaikan peralatan listrik rumah tangga bagi masyarakat Rukun Warga 09 Kelurahan Bunulrejo/Kec. Blimbing - Kota Malang kepadawarga rukun warga 09, maka dapat diambil kesimpulan yaitu :

1. Membantu peserta dan memberikan tambahan ketrampilan pelatihan perawatan dan perbaikan peralatan listrik rumah tangga bagi masyarakat Rukun Warga 09 Kelurahan Bunulrejo/Kec. Blimbing - Kota Malang

2. Memperbanyak tambahan keterampilan kepada warga rukun warga 09 .Dengan demikian kegiatan pengabdian kepada masyarakat ini mendapatkan antusias yang tinggi dari peserta pelatihan dan mereka mengharapkan adanya tindak lanjut program pengabdian kepada masyarakat berikutnya.

\subsection{Saran}

1. Perlu adanya tindak lanjut dari kegiatan ini, terutama dalam memberikan bimbingan dan dorongan kepada peserta pelatihan tentang manfaat dari pelatihan perawatan dan perbaikan peralatan listrik rumah tangga bagi masyarakat Rukun Warga 09 Kelurahan Bunulrejo/Kec. Blimbing - Kota Malang

\section{DAFTAR PUSTAKA}

[1]. Badan Standarisasi Nasional. Persyaratan Umum Instalasi Listrik 2000 (PUIL 2000).

Jakarta: Yayasan PUIL, 2000.

[2]. E. Setiawan, Ir. Instalasi Arus Kuat. Jakarta: PT Bina Cipta, 1986

[3]. Harten, Edi Setiawan. 1981. Instalasi Listrik Arus Kuat 1. Bina Cipta. Jakarta.

[4]. Harten, Edi Setiawan. 1981. Instalasi Listrik Arus Kuat 2. Bina Cipta. Jakarta

[5]. Kismet Fadillah. Instalasi Motor Listrik. Bandung: PT Angkasa, 1999

[6]. Perusahaan Listrik Negara. Teknologi Jaringan Distribusi. Jakarta: Pusat Pendidikan dan Latihan, 1986.

[7]. Sumaryono, Marsudi. Petunjuk Keselamatan Kerja. Jakarta: Departemen Pendidikan dan Kebudayaan, 1998. 